\title{
The status of rhinoceroses in South African National Parks
}

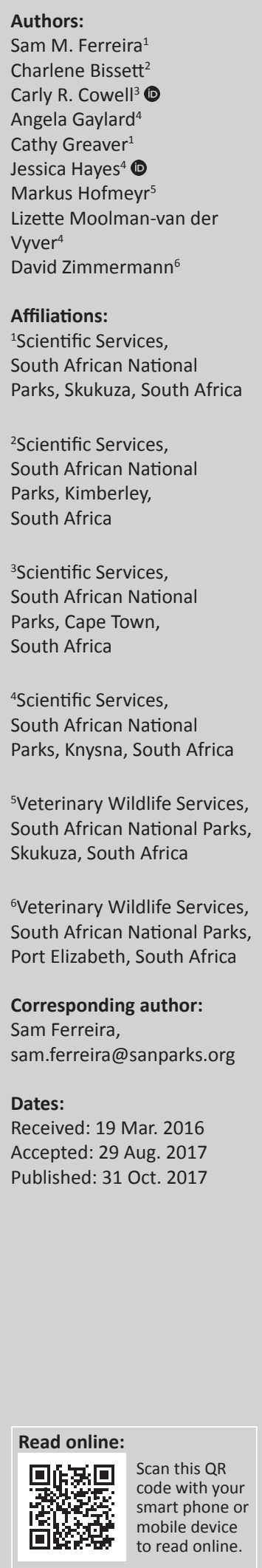

African rhinoceroses (rhinos) experienced a poaching onslaught since 2008 with the epicentre in South Africa where most of the world's rhinos occur. South African national parks, under the management of South African National Parks (SANParks), are custodian to $49 \%$ of South Africa's white and $31 \%$ of the country's black rhinos. We collated information on rhino population sizes in seven national parks from 2011 to 2015. We include and report on rhino surveys in Kruger National Park during 2014 and 2015. Southwestern black rhinos increased over the study period, which allows SANParks to achieve its contribution to South Africa's 2020 target of 260 individuals. South-central black rhinos declined over the study period because of poaching in the Kruger National Park, making it difficult for SANParks to realise a 9\% increase per annum for its expected contribution to the South African target of 2800 individuals. For southern white rhinos, SANParks requires 5\% annual growth for its contribution to the South African target of 20400 individuals. To continue to evaluate the achievement of these targets, SANParks needs annual population estimates relying on total counts, mark-recapture techniques and block-based sample counts to track trends in rhino populations. SANParks' primary challenge in achieving its contribution to South Africa's rhino conservation targets is associated with curbing poaching in Kruger National Park.

Conservation implications: The status and trends of rhino species in SANParks highlight key challenges associated with achieving the national targets of South Africa. Conservation managers will need to improve the protection of southern white rhino, while the Department of Environmental Affairs need to be made aware of the challenges specifically associated with not achieving targets for south-central black rhino. Outcomes for south-western black rhino have already realised and the good conservation efforts should continue.

\section{Introduction}

Rhinoceroses (rhinos) are under threat worldwide. Of the African rhinos, the southern white rhino Ceratotherium simum simum is the most abundant (Amin et al. 2006a), with its total numbers exceeding that of a minimum viable population (Reed et al. 2003). In contrast, the African black rhino sub-species experienced severe declines with the eastern black rhino Diceros bicornis michaeli and south-western black rhino Diceros bicornis bicornis listed as critically endangered and the south-central black rhino Diceros bicornis minor listed as vulnerable (Amin et al. 2006a). The northern white rhino Ceretatherium simum cottoni is functionally extinct (Groves, Fernando \& Robovský 2010) and the western black rhino Diceros bicornis longipes (Emslie 2011) recently went extinct (Travers, Waterland \& Stroud 2011). Asian rhinos (greater one-horn rhino Rhinoceros unicornis; Javan rhino Rhinoceros sondaicus and Sumatran rhino Dicerorhinus sumatrensis) all survive only in small numbers, with the Sumatran and Javan rhinos each with less than 100 in the wild. There were 3557 greater one-horn rhino by the end of 2015 (Emslie et al. 2016).

By 2014, South Africa was home to approximately $90 \%$ of the global population of southern white rhinos, and $36 \%$ of the world's black rhinos, consisting of south-western, south-central and a small extra-limital population of eastern black rhinos (Emslie et al. 2016). By then, the South African National Parks Board (SANParks) was custodian to roughly half of the white rhinos (49\%) and $31 \%$ of the black rhinos within South Africa (Emslie et al. 2016). South African national parks are thus home to a substantial proportion of the world's rhino and play a key role in ensuring their survival.

How to cite this article: Ferreira, S.M., Bissett, C., Cowell, C.R., Gaylard, A., Greaver, C., Hayes, J. et al., 2017, 'The status of rhinoceroses in South African National Parks', Koedoe 59(1), a1392. https://doi.org/10.4102/koedoe.v59i1.1392

Copyright: ( 2017 . The Authors. Licensee: AOSIS. This work is licensed under the Creative Commons Attribution License. 
Rhino conservation efforts, including anti-poaching, range from maximising species protection to restoring ecosystem processes. For instance, African rhino conservation plans typically seek to maximise population growth (e.g. Amin et al. 2006b; Knight, Balfour \& Emslie 2013; Milliken, Emslie \& Talukdar 2009; Mills et al. 2006), induce meta-population dynamics (Knight et al. 2013) and maintain genetic integrity (Emslie \& Brooks 1999; Karstens et al. 2011). Although the most serious threat to rhinos in Africa is poaching (Emslie 2013), intensified anti-poaching alone may not curb the poaching onslaught (Emslie 2013; Ferreira, Pfab \& Knight 2014; Ferreira \& Okita-Ouma 2012; Kagande \& Musarurwa 2014) and broader socio-economic approaches are required (Haas \& Ferreira 2016). Hence some plans incorporate social and economic objectives (Knight et al. 2015).

Several regional, national and international rhino conservation strategies and targets thus underpins SANParks' rhino management. The Black Rhino Biodiversity Management Plan (Knight et al. 2013) aims for a South African black rhino population growth rate of 5\% per annum, with 2800 south-central and 260 south-western black rhinos by the end of 2020. The White Rhino Biodiversity Management Plan (Knight et al. 2015) also aims for a white rhino population growth rate of 5\% per annum, with 20400 southern white rhinos by the end of 2020 in South Africa.

In addition to these rhino Biodiversity Management Plans (BMPs), South Africa's cabinet adopted an integrated four-pronged approach to curb rhino poaching during 2014 (Department of Environmental Affairs 2014). These are: (1) compulsory interventions to protect rhinos by implementing widespread and intensive anti-poaching programmes as well as creating particular zones of management using technology and intelligence, (2) game-changing interventions, targeted simultaneously at disrupting organised crime and creating opportunities for more equitable benefit-sharing of ecosystem services with all South Africans, (3) long-term sustainability interventions to explore the development of a legal and sustainable rhino trade system and (4) biological management interventions that focus on strategic removals from areas of high poaching risk to create rhino strongholds elsewhere. Biological management historically served as the core of South Africa's rhino conservation approach and successes (Knight et al. 2015).

As an identified implementing agency of the rhino BMPs, SANParks should contribute 22\% (538-676) and 65\% (169) of the individuals to the south-central and south-western black rhino targets for 2020, respectively, based on population estimates during 2014. For the southern white rhino, SANParks needs to contribute $49 \%$ (9854-10 232 individuals) of the 2020 targets.

As rhino conservation targets are set around rhino population sizes and growth rates, it is important to survey populations frequently to detect statistical changes. Estimates and trends allow for evaluating progress towards the targets, and assessing the effectiveness of current management interventions. Conservation authorities, however, face several challenges when counting and detecting trends in rhinos and other large animal population sizes. These relate to the feasibility of techniques at different population sizes and densities (Table 1), and sources of bias or error (e.g. Caughley 1974) linked to different methods and habitats. Optimal survey designs and intervals are thus contextspecific, influencing the precision and accuracy of counts (e.g. Ferreira \& Van Aarde 2009).

Although authorities recognise the effect of rhino poaching on southern white rhinos in Kruger National Park (Ferreira et al. 2015), there was no previous published attempt to quantify SANParks' overall progress towards the national rhino conservation targets across the SANParks estate. Moreover, SANParks have not yet assessed whether the techniques employed to count rhinos are optimal at current population sizes or densities. This study therefore aims to collate all SANParks' data on rhino population estimates for the period 2011-2015, across the range of methodologies employed to (1) evaluate the population status of southern white rhino, south-western and south-central black rhino populations in SANParks, (2) assess whether the techniques employed to count rhinos are optimal within park-specific contexts and (3) recommend optimal survey designs for the three sub-species in various National Parks. For south-central black and southern white rhinos in Kruger National Park we also derive estimates of recruitment rates (i.e. proportion of rhinos less than 1 year old reflect rhinos born and that survived the first year after birth) between two surveys and compare these to estimates of poaching rates. The results will allow us to evaluate SANParks' progress in achieving South Africa's rhino conservation targets and help inform management interventions.

\section{Material and methods}

\section{Study populations, data collection and collation}

The study populations include all rhinos in SANParks' protected areas from 2011 to 2015 (Appendix 1). Seven

TABLE 1: Survey techniques, situation suitability and supporting literature.

\begin{tabular}{|c|c|c|}
\hline Survey techniques & Suitability & References \\
\hline Strip-transects & $\begin{array}{l}\text { For medium to large mammalian } \\
\text { herbivores }\end{array}$ & Jolly (1969) \\
\hline Block counts & $\begin{array}{l}\text { For medium to large mammalian } \\
\text { herbivores }\end{array}$ & Ferreira et al. (2011) \\
\hline Distance sampling & For large mammalian herbivores & Buckland et al. (2004) \\
\hline Dung counts & $\begin{array}{l}\text { For populations with many } \\
\text { individuals/when individuals } \\
\text { occur over a wide area }\end{array}$ & $\begin{array}{l}\text { Ferreira et al. (2012); } \\
\text { Olivier et al. (2009) }\end{array}$ \\
\hline $\begin{array}{l}\text { Mark-recapture } \\
\text { techniques }\end{array}$ & $\begin{array}{l}\text { For populations with many } \\
\text { individuals/when individuals } \\
\text { occur over a wide area }\end{array}$ & $\begin{array}{l}\text { Ferreira et al. (2012); } \\
\text { Seber (1982) }\end{array}$ \\
\hline Call-up surveys & $\begin{array}{l}\text { For populations with many } \\
\text { individuals/when individuals } \\
\text { occur over a wide area }\end{array}$ & $\begin{array}{l}\text { Ferreira and Funston } \\
\text { (2010) }\end{array}$ \\
\hline Registration studies & $\begin{array}{l}\text { For populations with few } \\
\text { individuals }\end{array}$ & $\begin{array}{l}\text { Moss (2001); Patton, } \\
\text { Campbell and Parfet (2007) }\end{array}$ \\
\hline Total counts & For smaller areas & $\begin{array}{l}\text { Van Aarde, Whyte and } \\
\text { Pimm (1999) }\end{array}$ \\
\hline Aerial surveys & $\begin{array}{l}\text { For large mammalian herbivores. } \\
\text { Technique used to apply } \\
\text { strip-transects, distance } \\
\text { sampling and total counts }\end{array}$ & $\begin{array}{l}\text { Caughley (1974); Redfern } \\
\text { et al. (2002) }\end{array}$ \\
\hline
\end{tabular}


National Parks contain rhinos in a single management unit. Addo Elephant National Park has rhinos in three separate sections, but for analytical purposes we consider these combined. Rhinos experience different features and management histories in the various National Parks (Appendix 1). We collated data from all rhino census surveys that took place in these Parks during our study period.

South-western black rhinos occur in four National Parks: Addo Elephant, Mountain Zebra, Karoo and Mokala National Parks. In the Kuzuko Section of Addo Elephant National Park, field ranger patrols and game guides record daily sightings of individually recognisable rhinos, through ear notch patterns (Greaver, Ferreira \& Slotow 2014; Ngene et al. 2011). The Nyathi Section has low visibility in the mesic thicket vegetation and requires ground or cameratrap observations of individually marked rhinos. However, the presence of several un-notched rhinos that are not individually recognisable, challenges the maintenance of an up-to-date rhino register. Regular patrols, however, allow rangers to identify individuals by sex and age occurring in a specific area. Rangers monitor rhinos in the ColchesterMain Camp Section through individual observation from the ground or using aerial surveys. The populations of black rhino in Karoo, Mountain Zebra and Mokala National Parks are small enough to maintain a register of all individuals through observations of individually notched rhinos. We collated data on south-western black rhino from SANParks records (SANParks Unpublished data ${ }^{1}$ ) for Addo Elephant, Mountain Zebra, Karoo and Mokala National Park annually from 2011 to 2015.

South-central black rhinos occur in two National Parks: Marakele and Kruger National Parks. We extracted data for 2015 for Marakele from Ferreira and Greaver (2016). This study made use of a mark-recapture approach to estimate population size.

For Kruger National Park, we collated south-central black rhino data from Ferreira, Greaver and Knight (2011) as well as Ferreira et al. (2015). These publications provided estimates with 95\% confidence intervals for 2009 and 2013, respectively. To obtain estimates for 2011 and 2012, we used Monte-Carlo simulation techniques (Fishman 1995) to randomly draw from the probability distributions of the estimates collated for 2009 and 2013, and calculated an annual exponential growth rate (Caughley 1977).

Our study also made use of surveys targeting the southern parts of Kruger National Park during September 2014 and 2015 using block count techniques (Ferreira et al. 2011, 2015). The technique focused on surveying 470 and 487 randomly placed blocks $3 \mathrm{~km} \times 3 \mathrm{~km}$ in size during 2014 and 2015, respectively. Surveyors systematically completed transects comprising a $200 \mathrm{~m}$ observation strip on each side of a helicopter within each block with flights $45 \mathrm{~m}$ above ground at 65 knots. The survey team comprised a pilot, a data recorder and two observers. Using the block count data with an estimator (Jolly 1969) during 2014 and 2015 allowed landscape-specific estimates and overall estimates for Kruger National Park after accounting for the following biases: availability bias came from relationships between vegetation cover and rhino visibility (Ferreira et al. 2015), and observer bias came from estimates made during a previous survey (Ferreira et al. 2011). Detectability bias was minimal as the size of observation strips was narrower than it was in previous studies when detectability was noted as negligible (Kruger, Reilly \& Whyte 2008).

Using the observed age distribution and sex ratios, we could derive recruitment rates for Kruger National Park between the surveys of 2013 and 2014, as well as 2014 and 2015. This allowed us to compare the number of rhinos recruited through birth and first year survival in the total black rhino population with the number of rhinos poached between the two surveys. We thus collated poaching data in Kruger National Park for those periods (SANParks Unpublished records ${ }^{2}$ ).

Southern white rhinos occur in four National Parks - Kruger, Marakele, Mapungubwe and Mokala National Parks. We collated all southern white rhino observation data for these parks from 2011 to 2015. ${ }^{3}$ Annual and bi-annual helicopter surveys flying at a height of $50 \mathrm{~m}$ at a speed of 50-60 knots used $200 \mathrm{~m}$ wide transects to systematically cover a Park. This provided total counts of southern white rhinos at Mokala National Park and Marakele National Parks, respectively. Southern white rhinos in Kruger National Park also occur mostly south of the Olifants River. We collated estimates for 2011, 2012 and 2013 (Ferreira et al. 2012, 2015). During September 2014 and September 2015 we made use of the same survey and analytical approaches as used for south-central black rhinos in Kruger National Park. Rangers have a full record of every individual in Mapungubwe National Park based on regular observations.

\section{Analysis of trends in population estimates and growth rates}

We calculated sub-species-specific exponential growth rates for each park using an exponential model (Caughley 1977). For parks and species that included sample-based estimates with associated 95\% confidence intervals in any particular year we made use of Monte Carlo simulations (Fishman 1995) to define exponential population growth rates and their associated 95\% confidence intervals. For each year when a sample-based estimate was available, we extracted a value of the population size from the probability distribution defined by the estimate and its $95 \%$ confidence interval of that specific population estimate, and calculated exponential growth. We repeated this process 100000 times and calculated the median, as well as $2.5 \%$ and $97.5 \%$ percentiles as a definition

2.Data available from Ken Maggs, ken.maggs@sanparks.org

3.Data available from Cathy Greaver, cathy.greaver@sanparks.org and Charlene Bissett, charlene.bissett@sanparks.org 
of the $95 \%$ confidence interval. If the confidence intervals of exponential growth rates excluded zero, we concluded that a population is changing. This allowed us to identify the National Parks that play an important role in SANParks' ability to achieve contributions to national rhino objectives.

In order to evaluate SANParks' requirements to meet national targets by 2020, we calculated the annual rhino population growth rate required for each sub-species to reach the stipulated targets, given the population status during 2015 (see the 'Results' section). These evaluations allowed us to assess whether authorities require revised conservation interventions.

\section{Determining optimal survey requirements}

Surveying populations living at low densities present similar statistical challenges as surveying populations with few individuals. We generated a two-way matrix that describes the population sizes and densities of all rhino species in SANParks (Table 2). For ease of classification we defined population density categories on exponential scales. This allowed us to place a population in the smallest category based on size or density and identify the most suitable techniques given the category (Table 3).

As the survey techniques employed to estimate southcentral black and southern white rhinos had estimates of confidence intervals, and thus precision (i.e. the likely spread of estimates given the uncertainties introduced by biases such as availability, observer and detectability biases, see Caughley 1974 and Thompson 1992), these values allowed us to define optimal monitoring intervals directed at detecting required population growth. We used the required growth rates to achieve targets along with recorded confidence intervals to define optimal survey requirements using power analyses to detect trends (Gerrodette 1987). When designing optimal survey requirements, authorities need to trade-off the magnitude of change to detect, survey intervals, the number of surveys required and the total change by the time a trend is detected. This results in authorities deciding how many surveys and intervals are needed to obtain reliable data for detecting trends.

\section{Results \\ Contribution of various subpopulations to rhino population size targets}

Addo Elephant National Park makes the largest contribution towards south-western black rhino populations, with the combined numbers in Kuzuko, Nyathi and Colchester-Main Camp Sections comprising a minimum of 120 individuals (Table 4). Over half of the south-central black rhinos within SANParks occur in Kruger National Park (Table 4). Between the 2013 and 2014 surveys, the number of south-central black rhinos born that survived the first year in Kruger National Park was similar to the number of rhinos poached (Table 5). More south-central black rhinos were poached between the 2014 and 2015 surveys than what were born and survived the first year.

The block count of southern white rhinos in Kruger National Park produced an estimate of 8821 (95\% CI: 8335-9307) south of the Olifants River during 2015. This figure increased to a total of 8875 (95\% CI: 8365-9337) after including field ranger observations north of the Olifants River (Table 5). Elsewhere, an additional 252 individuals occur in Mapungubwe, Mokala and Marakele National Parks combined. More southern white rhinos were born and survived the first year than what were poached between the 2013 and 2014 surveys (Table 5). Between the 2014 and 2015 surveys, the number of rhinos born and surviving the first year were similar to that poached. This result confirms that, despite significant numbers of southern white rhino poached, Kruger National Park remains the most important contributor towards the conservation of wild free-ranging individuals of this species within its natural range in South Africa.

TABLE 2: Summary of rhino populations within South African National Parks in categories of population sizes (number of rhinos) and densities ( $\mathrm{n} . \mathrm{km}^{-2}$ ).

\begin{tabular}{|c|c|c|c|c|c|}
\hline \multirow[t]{2}{*}{ Number of Rhinos } & \multicolumn{5}{|c|}{ Density } \\
\hline & $\begin{array}{l}\text { Density very low: Very } \\
\text { low density of rhinos }\end{array}$ & $\begin{array}{l}\text { Density }<0.01 \mathrm{n} . \mathrm{km}^{-2}: \\
\text { Low density of rhinos }\end{array}$ & $\begin{array}{l}\text { Density } 0.01 \mathrm{n} \cdot \mathrm{km}^{-2}- \\
<0.1 \mathrm{n} \cdot \mathrm{km}^{-2}: \text { Medium } \\
\text { density of rhinos }\end{array}$ & $\begin{array}{l}\text { Density } 0.1 \mathrm{n} \cdot \mathrm{km}^{-2}-<1.0 \\
\text { n.km-2: High density of } \\
\text { rhinos }\end{array}$ & $\begin{array}{l}\text { Density } 1.0+\mathrm{n} \cdot \mathrm{km}^{-2} \text { : Very } \\
\text { high density of rhinos }\end{array}$ \\
\hline $\begin{array}{l}\text { Number of Rhinos < 20: Very } \\
\text { low number of rhinos }\end{array}$ & $\begin{array}{l}\text { Mapungubwe - SWR } \\
\text { Mountain Zebra - SWBR } \\
\text { Karoo - SWBR } \\
\text { Addo Elephant Kuzuko - } \\
\text { SWBR } \\
\text { Mokala - SWBR }\end{array}$ & - & - & - & - \\
\hline $\begin{array}{l}\text { Number of Rhinos } \\
100-<1000: \text { Medium } \\
\text { number of rhinos }\end{array}$ & - & - & Kruger - SCBR & Marakele -SWR & - \\
\hline $\begin{array}{l}\text { Number of Rhinos } \\
1000-<2000: \text { High } \\
\text { number of rhinos }\end{array}$ & - & - & - & - & - \\
\hline $\begin{array}{l}\text { Number of Rhinos } 2000+: \\
\text { Very high number of rhinos }\end{array}$ & - & - & - & Kruger - SWR & - \\
\hline
\end{tabular}

We provide names of the National Parks. Note that Addo Elephant National Park has three different sections where south-western black rhinos occur. We provide categorisation in a two-way matrix based on absolute number of rhinos as well as density of rhinos because parks have very different areas.

SWR, southern white rhino; SWBR, south-western black rhino; SCBR, south-central black rhino. 


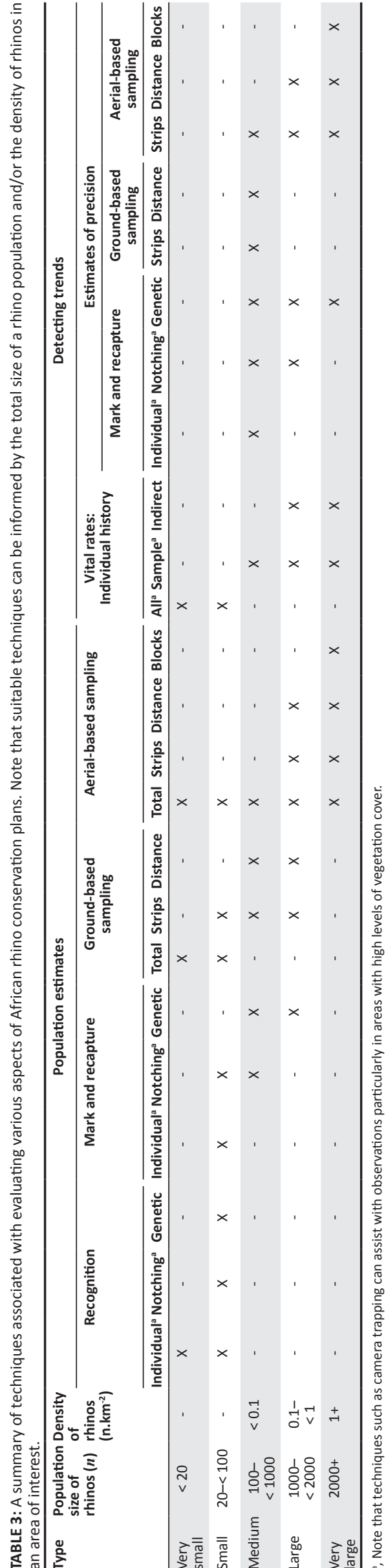

\section{Contemporary trends and requirements to meet conservation targets}

South-western black rhinos increased at a rate of 0.17 (95\% CI: 0.10-0.25) per annum from 2011 to 2015, based on annual exponential growth calculated using observed total population estimates. During 2015, SANParks was already contributing 166 individuals of the 169 that SANParks must contribute to the 260 south-central black rhino required by 2020. If SANParks maintain trends noted from 2011 to 2015, 388 (95\% CI: 186-810) south-western black rhinos will reside in South African National Parks by 2020. The SANParks target is achievable assuming that the current constraints on SANParks south-western black rhinos do not change substantially.

SANParks' south-central black rhinos declined overall at an annual exponential rate of -0.11 (95\% CI: -0.03 to -0.18$)$. In Kruger National Park from 2011 to 2015 there was an exponential decline of -0.15 (95\% CI: -0.05 to -0.25$)$, largely as a result of rhino poaching, which overrode the exponential annual rate of 0.48 (95\% CI: 0.26-0.69), because of management introductions, at Marakele National Park. If SANParks is to contribute 538-676 individuals to meet the South African target of 2800 south-central black rhinos by 2020, this will require SANParks' south-central black rhinos to reach an annual exponential growth rate of 0.09 (95\% CI: 0.02-0.18) from 2016 to 2020 .

Southern white rhino populations occurring in the parks outside of Kruger National Park increased at a rate of 0.14 (95\% CI: 0.10-0.19), partly because of introductions from Kruger. However, these populations contributed only $3 \%$ to the total number of southern white rhinos occurring in South African National Parks (Table 4). Within Kruger National Park, southern white rhinos may be declining at an exponential rate of -0.05 (95\% CI: 0.01 to -0.09) from 2011 to 2015, because of rhino poaching. As a result, SANParks' southern white rhinos exhibited at best a fluctuating population overall. If SANParks is to contribute the required 9854-10 232 individuals to the 20400 target of southern white rhinos in South Africa, their populations will need to increase at an annual exponential rate of 0.03 (95\% CI: 0.01-0.05) from 2016 to 2020. This is unlikely if the current rates of poaching are sustained.

\section{Optimal survey intervals and requirements}

Survey methods for south-western black rhinos (Table 4) do not allow for estimates of confidence intervals and hence do not allow definition of optimal surveys through trade-offs (Gerrodette 1987). Consequently, south-western black rhino numbers require estimation on an annual basis making use of total counts as before and mark-recapture techniques in future using ear-notching (Greaver et al. 2014; Ngene et al. 2011) and or genetic marking (Brook et al. 2012).

In contrast, estimates for SANParks' south-central black rhinos made it possible to generate coefficients of variance 
TABLE 4: Population estimates of various subspecies of rhinos within South African National Parks. We provide $95 \%$ confidence intervals for estimates that made use of formal statistical techniques.

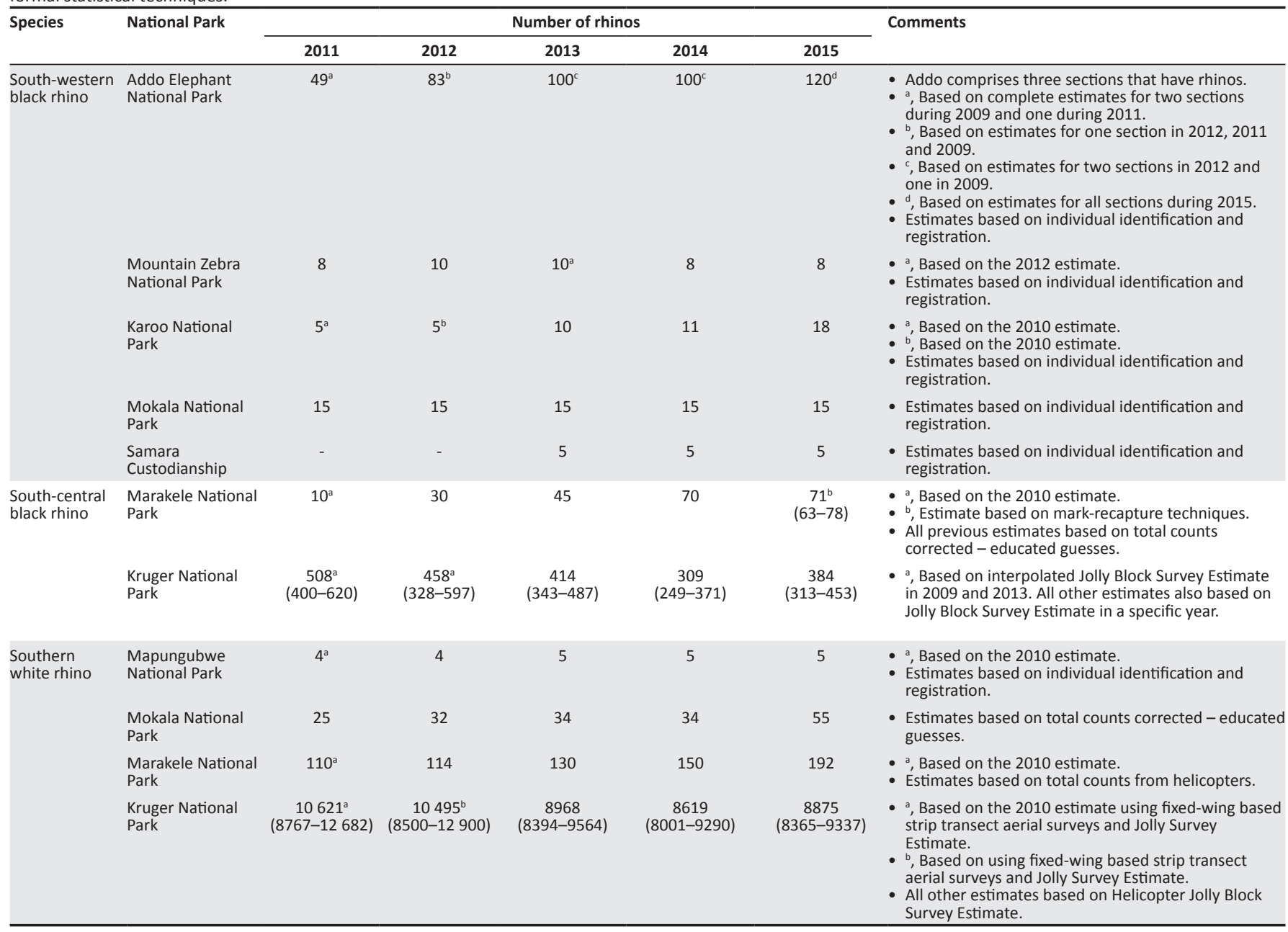

TABLE 5: A summary of first year recruitment (the number of rhinos born and surviving the first year of life) and poached individuals recorded for south central black rhinos and southern white rhinos in Kruger National Park between the 2013, 2014 and 2015 surveys.

\begin{tabular}{lcc}
\hline Survey intervals & First year recruitment & Poached rhinos \\
\hline South-central black rhino & $18-26$ & 17 \\
$2013-2014$ & $29-42$ & 52 \\
$2014-2015$ & & \\
Southern white rhino & $854-992$ & 745 \\
$2013-2014$ & $725-810$ & 818 \\
$2014-2015$ & & \\
\hline
\end{tabular}

(8\% during the study period) with which optimal survey intervals could be calculated. Two surveys between 1 and 4 years apart are needed to detect the required annual increase from 2016 to 2020. At this survey interval, there is a trade-off with the total amount of change detected at the time of the second survey's completion. If declining trends continue as at present, a total reduction of $11 \%$ south-central black rhinos will be detected during two surveys 1 year apart. In contrast, a total reduction of $44.2 \%$ individuals will be detected with surveys every 4 years (e.g. 2016-2020). Optimal survey intervals for south-central black rhinos should also be annual. Techniques should focus on block counts and mark-recapture estimates in Kruger National Park and mark-recapture approaches elsewhere.
Estimates of southern white rhinos living in South African national parks had a coefficient of variance of $5 \%$ at the end of 2015. To detect an annual decline of -0.05 as well as the required annual exponential increase of 0.05 from 2016 to 2020, SANParks can estimate southern white rhinos twice with surveys 1-4 years apart. The total change after 1 year, if potential declining trends realise (i.e. $5 \%$ decline in numbers), carries less risk than the total change after 4 years (i.e. $22.6 \%$ decline in numbers). Southern white rhinos thus also require annual estimates. Techniques should focus on block counts in Kruger National Park and total counts elsewhere.

\section{Discussion}

SANParks play a key role in the conservation of three subspecies of rhino within free-ranging conditions in South Africa. For south-central black rhinos and southern white rhinos, however, contemporary trends predict that SANParks will not be able to meet contributions to South Africa's rhino population targets if observed annual population growth rates remain the same.

Encouraging is the significant increases noted for southwestern black rhinos living in Addo Elephant, Mountain Zebra, Karoo and Mokala National Parks. The observed 
annual growth exceeds the physiological capability of southwestern black rhinos - having their first calf at 5-11 years of age, and at best, a calf every 2 years thereafter (Hitchins \& Anderson 1983). The high observed annual growth can result from small population effects on accuracy and precision of population estimates (Gerrodette 1987), accentuating estimated vital rates (Akcakaya 2002). High population growth can also result from conservation husbandry seeking to maximise population growth, including skewing sex ratios (Holand et al. 2003) and moving rhinos to maximise the social requirements of individuals (Reid et al. 2007). Over the past 5 years, SANParks moved three south-western black rhinos between four National Parks, placed five under custodianship and introduced an additional seven individuals from elsewhere into National Parks. The overall growth comes from having a female sex skew resulting from the initial introductions and high female calving rate in the initial years after introduction.

The trends noted for the numbers of south-central black rhinos in Marakele and Kruger National Parks significantly contrasts numbers noted for south-western black rhinos. Overall, south-central black rhinos occurring in South African National Parks declined from 2011 to 2015. Even so, the numbers of south-central black rhinos in Marakele National Park increased significantly over a 5-year period. Similar factors influence this trend as for the south-western black rhino population. Importantly the introduction of a robust mark-recapture estimate during 2015 (Ferreira \& Greaver 2016) compared to the records on individual rhinos used for the previous year's may also contribute. Even so, the 2015 survey highlights that Marakele National Park performs well (Ferreira \& Greaver 2016). The trends in numbers of southcentral black rhinos in Kruger National Park dominate in South African National Parks. At Kruger, south-central black rhino numbers declined significantly over a 5-year period.

Southern white rhinos occurring in South African National Parks followed similar trends to south-central black rhinos where combined numbers, in the three small populations, in Mokala, Marakele and Mapungubwe National Parks increased from 2011 to 2015. In Kruger National Park confidence intervals of estimates from 2011 to 2015 overlapped, but point estimates suggest $1 \%$ increase to a potential $9 \%$ decline. Kruger National Park is thus a key park that influence SANParks' ability to contribute to South Africa's rhino conservation objectives by 2020 .

Many of these patterns across South African National Parks result from disruptive effects of poaching on rhinos, particularly in Kruger National Park (Ferreira et al. 2015). From 2011 to 2015, poachers killed one rhino in Mapungubwe, five in Marakele and a staggering 2936 in Kruger National Park (SANParks Unpublished data ${ }^{4}$ ). A key question is: what would have been the rhino losses if SANParks had not implemented an integrated approach through the rhino protection in the smaller parks, anti-poaching in Kruger National Park and biological management across South
African national parks? Nonetheless, curbing rhino poaching in Kruger National Park remains the highest priority for SANParks' contribution to South Africa's rhino initiatives.

The status of rhinos in South African national parks at the end of 2015 provides guidelines for requirements to achieve the 2020 targets. That in itself is challenging. Contemporary trends in south-western black rhinos suggest the 2020 contribution will easily be met by SANParks if conditions prevail. Sustaining the contemporary trends is unlikely as annual growth rates recorded are higher than what optimal survival and fecundity schedules predicts for closed populations (Rachlow \& Berger 1998). SANParks can enhance population performances through conservation husbandry in Addo Elephant, Mountain Zebra, Karoo and Mokala National Parks that seeks to skew sex ratios in favour of adult cows and introducing more young adult cows. Removals of existing rhinos to skew sex ratios should focus on sub-adult males.

Even so, biological management interventions require more land - removed sub-adult males need localities to contribute to creating new populations; however, southwestern black rhinos notoriously have density-dependent social constraints that impose on interventions such as translocations (SANParks Unpublished data ${ }^{5}$ ). Several other South African national parks, such as Tankwa Karoo, Namaqua, Richtersveld, Kalahari, Augrabies and Cambedoo National Parks that may have suitable habitat within the historical distribution of south-western black rhinos (Skead 1980) provide additional options, but currently do not have security measures in place or do not have adequate fencing. A further challenge is to source young adult cows. By 2014, Namibia was the stronghold for south-western black rhinos (AfRSG Unpublished data $^{6}$ ). The rise in poaching incidents in Namibia (AfRSG Unpublished data ${ }^{7}$ ) reduces the likelihood of sourcing south-western black rhinos from there. An encouraging prospect is that SANParks' conservation husbandry approach from 2011 to 2015 resulted in an inflated increase in south-western black rhino numbers within South African national parks.

South-central black rhinos require a $9 \%$ increase in numbers per annum to reach the SANParks contribution to South Africa's 2020 target. This exceeds the maximum growth predicted by best survival, the ages at which cows have their first calves (Hitchins \& Anderson 1983) and how often thereafter (Ferreira et al. 2011; Hitchins \& Anderson 1983). In addition, SANParks only have two parks where southcentral black rhinos occur within their natural distribution. Conservation husbandry and expanding Marakele National Park (Ferreira \& Greaver 2016) should continue, but these practices were not enough to compensate for the losses experienced in Kruger National Park from 2011 to 2015. The poaching onslaught in Kruger National Park is the most 5.Dave Žmmermann, SANP.arks, dave.zimmermann@ @anparks.org

6.African Rhino Specialist Group, Mike Knight, mike.knight@sanparks.org

7.African Rhino Specialist Group, Mike Knight, mike.knight@sanparks.org 
significant threat to SANParks' ability to achieve its southcentral black rhino target by 2020 .

The 5\% annual increase required for southern white rhino populations is biologically realistic. In fact, the age at which a cow has her first calf, along with birth intervals and survival rates (Owen-Smith 1988) predict $>5 \%$ potential annual growth rates. For instance, southern white rhinos realised 9\% annual growth in Kruger National Park prior to the poaching onslaught that began in 2008 (Ferreira \& Okita-Ouma 2012).

SANParks should continue to implement rhino protection in small parks, anti-poaching in Kruger National Park and biological management across all of its national parks. Implementation has borne some results - in the 18 months before the end of 2015, only one rhino was confirmed poached in the small parks (SANParks Unpublished data ${ }^{8}$. The number of confirmed rhinos poached in Kruger National Park was one less during 2015 (826) compared to 2014 (827) (SANParks Unpublished data ${ }^{11}$ ). This contrasts the pattern from 2008 to 2014 when there was a $32 \%$ annual increase in the number of rhinos poached (SANParks Unpublished data ${ }^{11}$ ). SANParks anticipate that the full implementation of zone-, technology- and intelligencedriven anti-poaching in Kruger National Park will provide improved control of poaching within the park. If complimented with game-changing interventions, including disrupting organised crime (Haas \& Ferreira 2015) and empowering people (Lunstrum 2013) outside the park, authorities can curb rhino poaching. Several ongoing national and international collaborations, as well as new initiatives could aid in ensuring the long-term persistence of rhinos in Kruger National Park.

The results of our analysis suggest three key directives for conserving south-central black rhinos: (1) the existing conservation targets require revision of the $5 \%$ annual increase requirements in the Black Rhino Biodiversity Management Plan (Knight et al. 2013). Given the effect of poaching (Ferreira et al. 2015), the targeted numbers of SANParks' contribution will require higher annual growth rates, (2) taking control and curbing the effect of poaching on south-central black rhinos in Kruger National Park requires urgent interventions including a prioritised security response using interdiction patrol and hot pursuit tactics (Haas \& Ferreira 2017; Park et al. 2016) informed by predictions of spatial distribution of rhinos (Rachlow, Kie \& Berger 1999) extracted from intensive biological monitoring programmes and (3) we recommend that land for use by south-central black rhinos be increased. The northern part of Kruger National Park provides an ideal opportunity for expansion. Although south-central black rhinos mostly occur in southern Kruger at present, rangers noted several cases of southcentral black rhinos previously using landscapes in northern Kruger (Ferreira et al. 2011). Expansion into the area can only be considered if authorities adequately address the internal and external factors driving rhino poaching in the park.

8.Ken Maggs, SANParks, ken.maggs@sanparks.org

\section{Conclusion}

The trends of two of the three sub-species of rhinos in national parks are of key concern. Poaching, specifically in Kruger National Park, has disrupted the ability of SANParks to achieve its contribution to South Africa's rhino conservation targets for 2020. Achieving targets is feasible for southwestern black rhinos, less so for southern white rhinos, and most challenging for south-central black rhinos. This requires SANParks to continue to implement compulsory anti-poaching and innovative biological management interventions in Kruger National Park. For monitoring, it is critical that SANParks undertakes annual assessments of rhino population status in order to detect trends in population growth. For south-western black rhinos, registration studies that make use of a variety of individual recognition techniques including ear notching and genetic markers obtained through direct, indirect and technology-based observations provide for SANParks needs. South-central black rhinos require mark-recapture and aerial sample-based approaches, while southern white rhinos need aerial total counts and sample-based approaches. Ensuring funding to undertake the surveys, as well as capacity to perform the analysis, needs emphasis. The lessons learnt from this study are similarly applicable to surveys of large mammalian herbivores, particularly those undergoing either rapid increases or declines.

\section{Acknowledgements}

We are grateful for the assistance provided during the Kruger National Park surveys. We would like to thank observers Ben Wigley, Scott Ronaldson, Steven Khosa, Marius Renke, Etienne le Roux, Adolf Manganyi, Corli Wigley, Pauli Viljoen, Isaac Sibiya, Izak Smit and Elana Mol. We also thank pilots John Bassi, Grant Knight, Charles Thompson, Jaco Mol and Brad Grafton. We appreciate the support from SANParks senior management for census requirements during resource restricted times.

\section{Competing interests}

The authors declare that they have no financial or personal relationships that may have inappropriately influenced them in writing this article.

\section{Authors' contributions}

S.M.F. was responsible for study conceptualisation, analyses, report writing and editing. C.B., A.G. and C.G. were responsible for data collection and contributed to study design, report writing and editing. C.R.C., J.H., M.H., L.Mv.d.V. and D.Z. contributed to report writing and editing.

\section{References}

Akşakaya, H.R., 2002, 'Estimating the variance of survival rates and fecundities', Animal Conservation 5, 333-336. https://doi.org/10.1017/S1367943002004092

Amin, R., Okita-Ouma, B., Adcock, R., Emslie, R., Mulama, M. \& Pearce-Kelly, P., 2006b, 'An integrated management strategy for the conservation of Eastern black rhinoceros, Diceros bicornis michaeli, in Kenya', International Zoo Yearbook 40 118-129. https://doi.org/10.1111/j.1748-1090.2006.00118.x 
Amin, R., Thomas, K., Emslie, R.H., Foose, T.J. \& Van Strien, N., 2006a, 'An overview of the conservation status of and threats to rhinoceros species in the wild',
International Zoo Yearbook 40, 96-117. https://doi.org/10.1111/j.1748-1090. 2006.00096.x

Brook, S.M., Van Coeverden de Groot, P., Scott, C., Boag, P., Long, B., Ley, R.E. et al., 2012 , 'Integrated and novel survey methods for rhinoceros populations confirm the extinction of Rhinoceros sondaicus annamiticus from Vietnam', Biological Conservation 155, 59-67. https://doi.org/10.1016/j.biocon.2012.06.008

Buckland, S.T., Anderson, D.R., Burnham, K.P., Laake, J.L., Borchers, D.L. \& Thomas, L., 2004, Advanced distance sampling, Oxford University Press, New York.

Caughley, G., 1974, 'Bias in aerial survey', The Journal of Wildlife Management 38(4), 921-933. https://doi.org/10.2307/3800067

Caughley, G., 1977, Analysis of vertebrate populations, John Wiley \& Sons, New York.

Department of Environmental Affairs, 2014, Minister Edna Molewa leads implementation of integrated strategic management of rhinoceros in South Africa, viewed 23 February 2017, from https://www.environment.gov.za/
mediarelease/molewa_integratedstrategicmanagement_rinoceros

Emslie, R., 2011, Diceros bicornis ssp. Longipes, IUCN 2011, IUCN Red List of Threatened Species, Version 2011.2.

Emslie, R.H., 2013, African rhinoceroses - Latest trends in rhino numbers and poaching, An update to Doc 54-2-Annexe 2 from the IUCN Species Surviva Commission's (IUCN/SSC), African Rhino Specialist Group to the CITES Secretaria pursuant to Resolution Conf. 9.14, (Rev. CoP15) CITES CoP16 Inf Doc 51.

Emslie, R. \& Brooks, M., 1999, African Rhino. Status survey and conservation action plan, IUCN/SSC African Rhino Specialist Group, IUCN, Switzerland. ix + 92 pp.

Emslie, R.H., Milliken, T., Talukdar, B., Ellis, S., Adcock, K. \& Knight, M.H., 2016, African and Asian Rhinoceroses - Status, conservation and trade, CoP17 Doc.68, Annex 5 , viewed 23 February 2017, from https://cites.org/sites/default/files/eng/cop/17/ WorkingDocs/E-CoP17-68-A5.pdf

Ferreira, S.M., Botha, J.M. \& Emmett, M.C., 2012, 'Anthropogenic influences on conservation values of white rhinoceros', PLoS One 7(9), e45989. https://doi. conservation values of white rhino
org/10.1371/journal.pone.0045989

Ferreira, S.M. \& \& Funston, P.J., 2010, 'Estimating lion population variables: Prey and disease effects in Kruger National Park, South Africa', Wildlife Research 37(3), 194-206. https://doi.org/10.1071/WR09030

Ferreira, S.M. \& Greaver, C.C., 2016, 'Re-introduction success of black rhino in Marakele National Park', African Journal of Wildlife Research 46(2), 135-138. https://doi.org/10.3957/056.046.0135

Ferreira, S.M., Greaver, C.C. \& Knight, M.H., 2011, 'Assessing the population Journalof Wildlife Research41(2),192-204. https://doi.org/10.3957/056.041.0206

Ferreira, S.M., Greaver, C., Knight, G.A., Knight, M.H., Smit, I.P.J. \& Pienaar, D., 2015 'Disruption of rhino demography by poachers may lead to population declines in Kruger National Park, South Africa', PLOS One 10(6): e0127783. https://doi. org/10.1371/journal.pone.0127783

Ferreira, S.M. \& Okita-Ouma, B., 2012, 'A proposed framework for short-, mediumand long-term responses by range and consumer States to curb poaching for and long-term responses by range and con
African rhino horn', Pachyderm 51, 52-59.

Ferreira, S.M., Pfab, M. \& Knight, M., 2014, 'Management strategies to curb rhino poaching: Alternative options using a cost-benefit approach', South African
Journal of Science $110(5-6), 1-8$. https://doi.org/10.1590/sajs.2014/20120055

Ferreira, S.M. \& Van Aarde, R.J., 2009, 'Aerial survey intensity as a determinant of estimating population sizes and trends for large herbivores', South African Journa of Wildlife Research 39, 181-191. https://doi.org/10.3957/056.039.0205

Fishman, G.S., 1995, Monte Carlo: Concepts, algorithms, and applications, Springer, New York.

Gerrodette, T., 1987, 'A power analysis for detecting trends', Ecology 68(5), 1364 1372. https://doi.org/10.2307/1939220

Greaver, C.C., Ferreira, S.M. \& Slotow, R., 2014, 'Density dependent regulation of the critically endangered black rhinoceros population in Ithala Game Reserve, South Africa', Austral Ecology, 39, 437-447. https://doi.org/10.1111/aec.12101

Groves, C.P., Fernando, P. \& Robovský, J., 2010, 'The sixth rhino: A taxonomic reassessment of the critically endangered northern white rhinoceros', PLoS One
$5(4)$, e9703. https://doi.org/10.1371/journal.pone.0009703

Haas, T. \& Ferreira, S.M., 2015, 'Federated databases and actionable intelligence: Using social network analysis to disrupt transnational wildlife trafficking crimina networks', Security Informatics 4, 1. https://doi.org/10.1186/s13388-015-0018-8

Haas, T.C. \& Ferreira, S.M., 2016, 'Combating rhino horn trafficking: The need to disrupt criminal networks', PLOS One, 11(11), p.e0167040. https://doi.org/ 10.1371/journal.pone.0167040

Haas, T.C. \& Ferreira, S.M., 2017, 'Optimal patrol routes: Interdicting and pursuing rhino poachers', Police Practice and Research, https://doi.org/10.1080/15614263. 2017.1295243

Hitchins, P.M. \& Anderson, J.L., 1983, 'Reproduction, population characteristics and management of the black rhinoceros Diceros bicomis minor in the Hluhluwe/ Comdor/Umfolozi Game Reserve Complex', South African Journal of Wildlife Research 13(3), 78-85.

Holand, $\varnothing$., Røed, K.H., Mysterud, A., Kumpula, J., Nieminen, M. \& Smith, M.E., 2003 , 'The effect of sex ratio and male age structure on reindeer calving', The Journal of Wildlife Management 67, 25-33. https://doi.org/10.2307/3803058
Jolly, G.M., 1969, 'Sampling methods for aerial censuses of wildlife populations' East African Agricultural and Forestry Journal 34, 46-49.

Kagande, S.M. \& Musarurwa, L.K., 2014, 'Conserving the African rhinoceros', Biodiversity and Conservation 23(2), 497-502. https://doi.org/10.1007/s10531013-0613-2

Karsten, M., Van Vuuren, B.J., Goodman, P. \& Barnaud, A., 2011, 'The history and management of black rhino in KwaZulu-Natal: A population genetic approach to assess the past and guide the future', Animal Conservation 14(4), 363-370. https://doi.org/10.1111/j.1469-1795.2011.00443.x

Knight, M.H., Balfour, D. \& Emslie, R.H., 2013, Biodiversity management plan for the black rhinoceros (Dicero,s bicornis) in South Africa 2011-2020, Government Gazette South Africa, 36096, pp. 5-76.

Knight, M.H., Emslie, R.H., Smart, R. \& Balfour, D., 2015, Biodiversity management plan for the white Rhinoceros (Ceratotherium simum) in South Africa 2015-2020, plan for the white Rhinoceros (Ceratotherium simum) in South
Department of Environmental Affairs, Pretoria, South Africa.

Kruger, J.M., Reilly, B.K. \& Whyte, I.J., 2008, 'Application of distance sampling to estimate population densities of large herbivores in Kruger National Park', Wildlife Research 35(4), 371-376. https://doi.org/10.1071/WR07084

Lunstrum, E., 2013, 'Green militarization: Anti-poaching efforts and the spatial contours of Kruger National Park', Annals of the Association of American Geographers, https://doi.org/10.1080/00045608.2014.912545

Milliken, T., Emslie, R.H. \& Talukdar, B., 2009, African and Asian rhinoceroses-status, conservation and trade, A report from the IUCN Species Survival Commission (IUCN/SSC) African and Asian Rhino Specialist Groups and TRAFFIC to the CITES Secretariat pursuant to Resolution Conf. vol. 9.14 (Rev. CoP15), viewed n.d., from
https://cites.org/sites/default/files/eng/cop/17/WorkingDocs/E-CoP17-68-A5.pdf

Mills, A., Morkel, P., Amiyo, A., Runyoro, V., Borner, M. \& Thirgood, S., 2006, 'Managing small populations in practice: Black rhino Diceros bicornis michaeli in the Ngorongoro Crater,
S0030605306000901

Moss, C.J., 2001, 'The demography of an African elephant (Loxodonta africana) population in Amboseli, Kenya', Journal of Zoology 255(2), 145-156. https://doi. org/10.1017/S0952836901001212

Ngene, S., Bitok, E., Mukeka, J., Okita-Ouma, B., Gakuya, F., Omondi, P. et al., 2011 'Census and ear-notching of black rhinoceros (Diceros bicornis michaeli) in Tsavo East National Park, Kenya', Pachyderm, 49, 61-69.

Olivier, P.I., Ferreira, S.M. \& Van Aarde, R.J., 2009, 'Dung survey bias and elephant population estimates in southern Mozambique', African Journal of Ecology 47(2), 202-213. https://doi.org/10.1111/j.1365-2028.2008.00983.x

Owen-Smith, R.N., 1988, Megaherbivores: The influence of very large body size on ecology, Cambridge University Press, Cambridge.

Park, N., Serra, E., Snitch, T. \& Subrahmanian, V.S., 2016, 'APE: A data-driven, behavioral model based anti-poaching engine', (to appear in) IEEE Transactions on Computational Social Systems, 2(2).

Patton, F., Campbell, P. \& Parfet, E., 2007, 'Establishing a monitoring system for black rhinos in the Solio Game Reserve, central Kenya', Pachyderm (43), 87-95.

Picard, N., Chagneau, P., Mortier, F. \& Bar-Hen, A., 2009, 'Finding confidence limits on population growth rates: Bootstrap and analytic methods', Mathematical Biosciences 219, 23-31. https://doi.org/10.1016/j.mbs.2009.02.002

Rachlow, J.L. \& Berger, J., 1998, 'Reproduction and population density: Trade-offs for the conservation of rhinos in situ', Animal Conservation 1, 101-106. https://doi. the conservation of rhinos in situ', Anima
org/10.1111/j.1469-1795.1998.tb00017.x

Rachlow, J.L., Kie, J.G. \& Berger, J., 1999, 'Territoriality and spatial patterns of white rhinoceros in Matobo National Park, Zimbabwe', African Journal of Ecology, 37, 295-304. https://doi.org/10.1046/j.1365-2028.1999.00175.x

Redfern, J.V., Viljoen, P.C., Kruger, J.M. \& Getz, W.M., 2002, 'Biases in estimating population size from an aerial census: A case study in the Kruger National Park, South Africa', South African Journal of Science 98(9 \& 10), 455-461.

Reed, D.H., O'Grady, J.J., Brook, B.W., Ballou, J.D. \& Frankham, R., 2003, 'Estimates of minimum viable population sizes for vertebrates and factors influencing those estimates', Biological Conservation, 113(1), 23-34. https://doi.org/10.1016/ S0006-3207(02)00346-4

Reid, C., Slotow, R., Howison, O. \& Balfour, D., 2007, 'Habitat changes reduce the carrying capacity of Hluhluwe-Umfolozi Park, South Africa, for critically carrying capacity of Hluhluwe-Umfolozi Park, South Africa, for critically
endangered black rhinoceros Diceros bicornis', Oryx 41, 247-254. https://doi. endangered black rhinoceros Dice
org/10.1017/S0030605307001780

Seber, G.A.F., 1982, The estimation of animal abundance, Backburn Press, Caldwell.

Skead, C.J., 1980, Historical mammal incidence in the Cape Province. Volume 1, The Western and Northern Cape, The Department of Nature and Environmental Conservation of the Provincial Administration of the Cape of Good Hope, Cape Town, pp. 277-311.

Thompson, S.K., 1992, Sampling, John Wiley \& Sons, New York.

Travers, W., Waterland, S. \& Stroud, A., 2011, 'Extinction of western black rhinoceros', CITES Afrique 4, 1-3.

Van Aarde, R., Whyte, I. \& Pimm, S., 1999, 'Culling and the dynamics of the Kruger National Park African elephant population', Animal Conservation 2(4), 287-294. https://doi.org/10.1111/j.1469-1795.1999.tb00075.x 


\section{Appendix 1}

TABLE 1-A1: Features of South African national parks where rhinos occur, along with a brief summary of rhino history in each park.

\begin{tabular}{ll} 
National Park & Features \\
\hline Addo Elephant & Addo Elephant National Park (AENP) is located in \\
National Park & the Eastern Province of South Africa and \\
stretches over several biomes including the & Nama Karoo, Fynbos, Forests, Thickets, \\
& Grasslands and azonal wetlands. The Park is \\
& $6860 \mathrm{~km}^{2}$ in size comprising formally declared \\
protected areas and contractual Parks. The Park & covers areas with summer rainfall north of the \\
& Zuurberg range and the all-year rainfall south of \\
& the mountain range. The climate is warm \\
& temperate with annual rainfall varying from \\
& 900 mm in the Alexandria forests to $350 \mathrm{~mm}$ in \\
& the northern Karoo rain-shadow areas. \\
& Temperatures vary from $15^{\circ} \mathrm{C}$ to $45^{\circ} \mathrm{C}$ in January \\
& and $5{ }^{\circ} \mathrm{C}$ to $18{ }^{\circ} \mathrm{C}$ in July.
\end{tabular}

Mountain Zebra National Park

Karoo National Park

Mokala National Park to east. KaN experiences cold winters (mean
Mountain Zebra National Park (MZNP) is situated in the Eastern Cape, on the Northern slopes of the Bankberg mountain range in the Cape Midlands. It is located in a transitional area between four biomes: Grassland, Nama Karoo, Thicket and Savanna. The climate of the park is best described as cool and arid. Mean monthly minimum and maximum temperatures vary from $6^{\circ} \mathrm{C}$ to $28^{\circ} \mathrm{C}$ in summer (September to March) and from $0^{\circ} \mathrm{C}$ to $20^{\circ} \mathrm{C}$ in winter (April to August). Rainfall averages about $400 \mathrm{~mm}$, with most $(70 \%)$ falling in the summer months.

Karoo National Park (KaNP) is situated in the Great Karoo, South Africa's largest ecosystem, covering $35 \%$ of its land area, against the Nuweveld Mountain range, some $3 \mathrm{~km}$ northwest of Beaufort West, in the Western Cape Province. KaNP thus falls within the Central Karoo District of the semi-arid Nama-Karoo environment. Mean annual rainfall ranges from $175 \mathrm{~mm}$ to $406 \mathrm{~mm}$ in different parts of the park, with $60 \%-75 \%$ falling in summer. Rainfall reliability, as expressed by the coefficient of reliability, as expressed by the coefficient of variation in annual rainfall, diminishes from west winter minimu summers (mean summer maximum temperature is $>32^{\circ} \mathrm{C}$ ).

Mokala National Park (MoNP) is located in the Northern Cape Province of South Africa and stretches over two biomes which include the Savanna and Nama Karoo. The Park is currently $283 \mathrm{~km}^{2}$. Negotiations are under way to expand the Park. The Park is situated in a semi-arid area that experiences erratic rainfall, falling mainly during summer. Average annual rainfall is around $400 \mathrm{~mm}$ per annum, ranging from $300 \mathrm{~mm}$ to $700 \mathrm{~mm}$ per year. Temperatures range from $-6^{\circ} \mathrm{C}$ during winter to $44^{\circ} \mathrm{C}$ during summer.

Rhino Species

South-western black rhino

Diceros bicornis bicornis

Rhino history

Seven D.b.michaeli were introduced into AENP between 1961 and 1962. By 1996 this population had increased to 35 individuals. All the D.b.michaeli were subsequently removed and replaced with the of $D$-western black rhino ecotype D.b.bicornis. The rentroduction re-establish only indigENP formed part of SANParks overall policy to parks. This reintroduction has gone through a number of phase extending over several isolated management units, as the park has expanded. At present there are three major areas that sustain the population:

1. The Darlington-Kuzuko Section, located in the Nama-Karoo biome $597 \mathrm{~km}^{2}$ in size, is at present divided into two sections: Kuzuko which is a bull camp only and Darlington Dam section $\left(445 \mathrm{~km}^{2)}\right.$ which has a breeding population of black rhino. The population at Darlington Dam was founded in 1999 with the reintroduction of five rhino from Augrabies Falls National Park. The population was reinforced with a bull from Tswalu in 2005, three (one male and two females) from Namibia in 2005, and a bull from Addo Main Camp in 2007. Three bulls have been removed from the population since the founding of the population. A total of 29 individuals have been notched since 2002. Three bulls were relocated to the Kuzuko section in 2005. This bull group has had various removals and introduction since then.

2. Nyathi Section $\left(145 \mathrm{~km}^{2}\right)$ is located in the forest-thicke transition. Between 1994 and 1997, eight black rhinos were reintroduced into this area and the population has since been supplemented with two bulls in May 2003 and June 2003, respectively. Since then there has been no further reinforcements of the population and no removals from the population. Fifteen individuals have been notched since 2003 . No rhinos have been poached.

3. The Colchester-Main Camp Section is unit $\left(287 \mathrm{~km}^{2}\right)$ and comprise mostly of the thicket biome. Between 1998 and 1999 SANParks introduced a founder population of 15 black rhinos, but experienced numerous mortalities relating to disease and post release stress from elephant-rhino conflict. The population has since been reinforced with two rhino from Tswalu Game Reserve in 2000, a Namibian bull in 2007 who died shortly after reserve in 2000, a Namibian bull in 2007 who died shortly after from Hunter's Moon in May 2012. Only one bull has been removed from the population since 2003. No rhinos have been removed from the population since 2003. No rhinos have been
poached. A total of 16 individuals were notched since 2003 .

South-western black rhino Diceros bicornis bicornis

Black rhino were reintroduced to MZNP $\left(214 \mathrm{~km}^{-2}\right)$ in March 2002 with a founder population of five individuals, composed of two adult bulls, two adult cows and a sub-adult bull. One of the adult bulls was subsequently removed in 2003 because of conflict with one of the adult cows. There has been no reinforcement of the population since the initial founder population was reintroduced and in May 2012 two sub-adult females were removed from the park and relocated to Karoo NP. One individual has been notched since 2002.

South-western black rhino Diceros bicornis bicornis

South-western black rhino Diceros bicornis bicornis Southern white rhino Ceratotherium simum simum
During 1993, SANParks reintroduced D.b. bicornis into KaNP $\left(898 \mathrm{~km}^{2}\right)$, but the population was subsequently removed to AENP and replaced with a small population of D.b.michaelis. Which were also eventually removed in 2002. D.b.bicornis were reintroduced for the second time in 2005 with two bulls from Tswalu Game Reserve. In 2007 five Namibian rhino reinforced the population and in May 2012 two sub-adult females were supplemented from MZNP. Two rhino have since been notched. No reported poaching incidents.
Six black rhino were reintroduced to Vaalbos National Park in 1987 from Namibia. Over the years a number of animals were removed. In 2006 the whole population, consisting of 8 individuals, were relocated to the present day MoNP. In May 2013 the breeding bull that had died was replaced by a bull from Kuzuko Section in AENP. In the same year five sub-adult bulls were removed and relocated, under a custodianship agreement, to Samara GR. Nine individuals have been notched. No reported poaching incidents. In January 1992 five white rhinos were relocated from Kruger National Park (KNP) to Vaalbos National Park. In 1999, 11 white rhinos were relocated from Vaalbos National Park to Tswalu Game Reserve. In 2005, one bull was removed from Vaalbos National Park. The initial reintroduction to MoNP was six individuals that were relocated from Vaalbos National Park in 2006, however one female died during relocation. Therefore the starter population was five individuals. In April 2007 an additional 11 animals were relocated from KNP to MoNP and in 2014 another 5 animals were relocated from KNP to MoNP. 
TABLE 1-A1(Continues...): Features of South African national parks where rhinos occur, along with a brief summary of rhino history in each park.

\section{National Park} Features

Mapungubwe National Mapungubwe National Park (MapNP) is located Park in the Limpopo Province on the South African side of the confluence of the Shashe and Limpopo Rivers. The park is a World Heritage Site and protects significant cultural and historical assets and is located in the Savanna Biome. The Park is $281 \mathrm{~km}^{2}$ in size comprising of formally declared protected areas and private land managed by SANParks and experience annual rainfall of $350 \mathrm{~mm}-400 \mathrm{~mm}$. Winters are mild, while summer temperatures may rise to $45^{\circ}$. Commiphora-Colophospermum veld unique tall Lowveld riparian woodland lines the main rivers.

Marakele National Park Marakele National Park (MaNP) is $639 \mathrm{~km}^{2}$ and located in the Savannah biome of the North West Province of South Africa, It includes the Marakele Park (PTY) Ltd. managed as a contractual park. Mountains and bottomlands dominate the landscape.

\section{Rhino Species}

Rhino history

Southern white rhino

Ceratotherium simum simum

SANParks introduced four southern white rhinos to MapNP during 2004. The population has remained small largely because of poor breeding and natural mortality, poaching and little additiona introductions. Since 2008 one rhino was poached in MapNP.
South-central black rhino Diceros bicornis minor Ceratotherium simum simum
The initial reintroduction of D.b.minor to MaNP was three individuals into the Waterval area (two from KNP and one from HluhluweImfolozi Park) during October 1993. Subsequent to that 25, additional black rhinos were introduced until 2007 . Five were moved out of the park between 2003 and 2008 and some internal moved out of the park between 2003 and 2008 and some inte attributed to natural causes. Regular notching events until 2013 attributed to natural causes. Regular notching events until 2013 unique ear markings to facilitate population monitoring. Southern whique ear markings to facilitate population monitoring. Southes were introduced to MaNP initially during 1996. Subsequent to the initial introduction, 93 additional white rhino were introduced from 2001 to 2015 from KNP. During 2003, two white rhinos were moved to Botswana and another five were removed from 2007 to 2013 .

South-central black rhino Diceros bicornis minor Southern white rhino Ceratotherium simum South-central black rhino went locally extinct and the last one was sighted during 1936. Reintroduction commenced in 1971, with a total of 81 black rhinos introduced by 1990 . By 2009 black rhinos were increasing at $6.8 \%(95 \% \mathrm{Cl}: 0.041-0.098)$ per annum and have reached a population size of 627 (95\% Cl: 588-666). South-eastern black rhino had high survival and an estimated inter-calving interval of 2.45 years. Age distributions and population growth suggested higher survival rates for dependent calves and adults compared to sub-adult males and females. The poaching onslaught since 2008 has resulted in a decline in the population. Several removals (six to
Liwonde National Park in Malawi, six to Venetia Game Reserve (seven were captured with one capture related mortality) 12 (13 (seven were captured with one capture related mortality), 12 (13 Were caught with one capture related mortality) to North Luangwa National Park in Zambia, six to Moremi Game Reserve in Botswana and two orphans were raised and sold to private owners before 2012) can influence population responses. Southern white rhinos were locally extinct by the turn of the 19th century. Authorities introduced 351 white rhinos between 1960 and 1972 sourced from Hluhluwe-iMfolozi Park. By the middle of the 1980 s, authorities started to remove rhinos from KNP as donations to other conservation areas and zoological gardens. The population proliferated and by the late 1990s, authorities sold/exchanged and donated annually between $0.1 \%$ and $1.6 \%$ of the white rhinos to private owners as part of a developing wildlife economy associated with southern white rhinos and to other conservation areas. Between 1995 and 2015, 1465 white rhinos were moved out of KNP. Twenty-seven rhino orphans ( 24 white rhino and three black rhino) were rescued from 2012 to 2015 during the increased poaching onslaught. Twenty-four of these orphans were still alive by the end of onslaught. Twenty-four of these orphans were still alive by the
2015. Even so, rhinos continue to colonise KNP with $77.1 \%$ of 2015. Even so, rhinos continue to colonise KNP with $77.1 \%$ of
landscapes having white rhinos present by 2010 . Since 2008 , the landscapes having white rhinos present by 2010 . Since 2008 , the
population was influenced by poaching as well as density- and rainfall-dependent responses in birth and death rates. 